\title{
Role of Mothers in Developing Responsibility Attitudes for Children Aged 4-6 Years During the Covid-19 Pandemic
}

\author{
Rohita $^{1, *}$ Nadhifah Rahmadini Hidayat ${ }^{1}$ \\ ${ }^{1}$ Education Teacher-Early Childhood Education Department, Faculty of Psychology and Education, University of Al \\ Azhar Indonesia \\ *Corresponding author. Email: rohita@uai.ac.id
}

\begin{abstract}
This study aims to describe the role of mothers in developing responsible attitudes for children aged 4-6 years during the COVID-19 pandemic. The research subjects were determined by purposive sampling involving 5 mothers with children aged 4-6 years. The main technique for collecting data is by filling out questionnaires through the Google Form application, with data coverage consisting of the role of mothers as facilitators, mediators, and motivators. The data obtained were analyzed using qualitative data analysis methods. The results show that three respondents carried out their roles as mediators and motivators, and two respondents carried out their roles as mediators and facilitators. Inconsistency, force, and high voices characterize the process of developing responsibility for children. This research implies the need for in-depth understanding of three roles of mothers in developing responsibility for children, as well as the characteristics of the development of children aged 4-6 years so that the responsibility developed is firmly attached to the children.
\end{abstract}

Keywords: Role of Mothers, Responsible, Children Aged 4-6 Years.

\section{INTRODUCTION}

At the beginning of 2020, the world was shocked by the emergence of a virus known as coronavirus or COVID-19. This impacted on the appearance of various policies issued by the government to protect the citizens. Among them is by implementing a Social Distancing policy which later was changed the term to Physical Distancing, which is the need to maintain distance between individuals so that they are not allowed to hold activities with a large number of people [1].

As a result of the Physical Distancing policy implementation, people are being "isolated" or work, study, and pray from home, so that there is more time spent together with family at home than before this policy was implemented. It is hoped that with plenty of time to gather with the family it can protect all members from the Coronavirus, produce a harmonious environment, and help children to develop optimally with the strong bond to their parents. This is in accordance with the statement of Werdiningsih \& Astarani [2] where the family environment is a factor that affects the growth and development of children. Family is the first community that can increase the maturity of a children through a process, such as seeing other people in a different social status, ethnicity, religion, race, and cultural background from themselves [3]. Parents, as leaders in the family, should be the role models for children because they are needed in the development process [4]. Therefore, parents can take full advantage of the COVID-19 pandemic to carry out their role in stimulating children's development more optimally.

Role is a set of behaviors expected from someone who occupies a certain position in the society [5]. Children need the parents' active role in their development, especially when they are under the age of five, because at that time children are in a period of 'initiative vs guilt' according to Erikson's psychosocial theory [6]. During this period, children learn to try to get a balance between their abilities and expectations or "goals" of their abilities. Thus, the role of parents is to support and build the children's confidence so they dare to try something new (initiative) and not feel guilty (guilt) if they fail is very necessary. 
Being parents means carrying out the roles properly in the family. In this study, the roles of parents include as motivators, facilitators and mediators for children. According to Nurmasita \& Rofiah [7] as motivators, parents must always provide motivation in the form of love, attention, encouragement, and the presence of parents by their side in the hope that children do good and stay away from being ill-behaved. As facilitators, parents need to provide facilities in order to meet the family basic needs in the form of clothing, food, shelter, including educational needs. As mediators, it means getting involved in the children's development. The implementation of these roles optimally can help children prepare themselves to enter their adult life later, including to have a responsible attitude.

Responsibility is the attitude and behavior of a person to carry out duties and obligations towards oneself, society, the environment (natural, social, and cultural), the country, and God Almighty [8]. Responsible attitudes and behaviors lead to the desires of others in the form of paying attention and actively responding to them [7]. The responsibility itself is divided into 4 levels [9], namely: 1). Level 4, people are more likely to have attitudes and behaviors that are very respectful, very responsible, helping others; 2). Level 3, people are more likely to have the attitude and behavior according to the task given and if there is an opportunity to provide assistance, their creativity exceeds expectations; 3 ). Level 2, people are more likely to have work attitudes and behaviors when reminded. The characteristic of this level is carrying out the task after being reminded or asked by an adult who comes; and, 4). Level 1, people are more likely to have non-work attitudes and behaviors. The characteristic at this level is that the task is done only a little or even incomplete and shows confusion. In addition, to develop responsibility for children, one can do it with the habituation method [8].

The reason for this research is recognizing the importance of mothers developing responsibility for their children and the absence of research results on this, especially during the Covid-19 pandemic. Thus, the purpose of this study is to describe the role of mothers in developing the responsibility attitude of children aged 46 years during the Covid-19 pandemic.

\section{METHOD}

The qualitative approach used in this research is descriptive qualitative research methods. The use is aimed to deepen the understanding of the role of mothers in developing responsible attitudes for children aged 4-6 years during the Covid-19 pandemic. The research subjects were determined by the researcher by purposive sampling, which were 5 mothers who have children aged 4-6 years, live in the Kemang area, South Jakarta, and were willing to be research subjects. This research was conducted in June - July 2020.

The technique used by researchers in collecting data was by filling out questionnaires through the Google Form application. The questionnaire consists of several questions which were divided into two parts with reference to the conceptual framework, namely related to the role of mothers in developing responsible attitudes for children aged 4-6 years, including roles as motivators, facilitators, and mediators. Furthermore, the results of data collection were described in appropriate and

Table 1. Questionnaire Guidelines

\begin{tabular}{|c|c|c|}
\hline No & Role of Mother & Activities \\
\hline \multirow[t]{5}{*}{$\mathbf{A}$} & Facilitator & Providing a place to store media to practice children's responsibility attitude \\
\hline & & Provide tools (media) to train children's responsibility attitudes \\
\hline & & Allowing children to choose clothes to wear \\
\hline & & Allow the children to determine the time to bathe \\
\hline & & Determine the games that the children will play \\
\hline \multirow[t]{8}{*}{$\mathbf{B}$} & Mediator & Provide time to be with children \\
\hline & & Give the opportunity to children to make a mutual agreement \\
\hline & & Give leeway to children to disobey agreements that have been made together \\
\hline & & Remind children about collective agreements when children start breaking the agreement \\
\hline & & Talking in a high voice to the children \\
\hline & & Allowing children not to tidy up/complete activities \\
\hline & & Give the children the opportunity to apologize immediately when they make a mistake without scolding them first \\
\hline & & Forcing children to tidy up their toys \\
\hline \multirow[t]{4}{*}{$\mathbf{C}$} & Motivator & Give praise to children when they achieve success \\
\hline & & Encourage children when children are tired of doing something \\
\hline & & Giving gifts (toys, favorite food, going on trips, etc.) when children achieve success \\
\hline & & Give punishment if the children does not carry out their responsibility \\
\hline
\end{tabular}


systematic language based on the answers of the research subjects. The data that has been obtained through filling out the questionnaire were analyzed using qualitative data analysis methods. The table 1 presents a questionnaire guideline for data collection.

\section{RESULT AND DISCUSSION}

Based on the results, information is obtained that all subjects know the meaning of responsibility, even though delivered differently. According to them, responsibility is an attitude that must be done by children according to their age, an attitude of guilt and correcting mistakes from within, an attitude that bears the consequences of an act that is done, and an attitude when someone can do things on their own. This is in accordance with what was conveyed by Surifah, et al. [8] where responsibility is a person's attitude and behavior to carry out their duties and obligations towards oneself, society, the environment (natural, social, and cultural), the country, and God Almighty. Regarding the implementation of the mother's role in developing responsibility and as a facilitator, it is seen that $100 \%$ of respondents provide a place to store media to practice children's responsibility attitudes and allow children to choose the clothes to wear. In relation to the games that children want to play, $80 \%$ stated that they did not determine the games, meaning that children were given the freedom to make choices. Then, as many as $60 \%$ of respondents stated that they did not provide tools (media) to practice children's responsibility attitudes and did not allow children to determine their own time to bathe. Even though in the book develops responsibility for children issued by the Ministry of Education and Culture of the Republic of Indonesia through the Sahabat Keluarga program [10], letting children make decisions is one way to develop responsibility for them and the obligation of parents to provide a safe, comfortable, and pleasant environment for them including media or tools to support that development.

For the role as a mediator, about the time spent by mothers with children, it is known that all subjects spent time during the Covid-19 pandemic to carry out activities with children especially in developing their responsibility attitude for more than 6 hours. The 6 hours a day that mothers spend with their children at home is certainly not a short time. Many things can be done including in developing their responsibilities. The success of the mothers can be seen from the ability shown by the children, including being able to put sandals or shoes in place $(100 \%)$, close the tap after use $(100 \%)$, wash hands after playing from outside the house (100\%), throw garbage in the bin $(100 \%)$, maintain one's own belongings $(80 \%)$, and apologize when making mistakes $(80 \%)$. What the children have done is in accordance with the abilities that the children should have according to the indicators of responsible attitude and behavior as stated by Haryani, et al. [11], Abdussalam [12], and Ramiyati, et al. [13].

However, in order to the children to be truly responsible, they must find the benefits of the things they do by themselves, so the mothers' ability to explain this to the children is needed. The interaction of the children with the environment in the sense that they do their task directly, accompanied by and seeing examples of what their mothers did, will be able to increase the children's knowledge and also give understanding and experience of what is meant by responsibility along with the reasons and benefits. This is as stated by Piaget with his constructivist theory that "children create knowledge through interactions with the environment"; and also Vigotsky who has the view that "the learners as an active participant in constructing his own learning within the context of interactions with caregivers, a family or community, and a society" [14]. What the mothers do also shows that the subject has implemented the role of a good mediator, because the characteristic of the mediator is that they are involved in the children's development process [7].

In carrying out the role as a mediator, the mothers also gave children the opportunity to make a collective agreement, reminds the children about the agreement that has been made, gives the opportunity to immediately apologize without scolding first, and does not allow the children not to tidy up his toys or not complete his activities. This was done by $100 \%$ of respondents. Furthermore, it is also known that $60 \%$ of respondents allow children to disobey the agreements that have been made by providing concessions in its implementation, $80 \%$ of respondents speak in a high voice to their children, and, $60 \%$ of respondents force the children to tidy up the toys that have been used. As a mediator, the mothers have implemented 3 of the 7 indicators. Meanwhile, the other 4 cannot be done properly. Allowing the mothers to break the agreement can cause confusion for the children as well as an opening to try to break other agreements that have been made. Consistency is needed from the mothers to be able to implement the agreement so that the efforts to develop responsibility can be optimally achieved. Haswell, Hock, \& Wenar (1981); Kochanska \& Aksan (1995); Kopp (1982); Kuczybksi \& Kochanska (1995); Power \& Chapieski (1986) in Papalia, Olds, and Feldman [15] wrote to "be consistent in enforcing necessary requests". Mothers' consistency in carrying out the agreement teaches children to be consistent in implementing the rules. Also, obeying the rules is one of the responsible behavior [10]

Another thing that mothers do in carrying out their role as a mediator is to force children to tidy up their toys even with a high voice. Forcing is actually not the right thing to do, because every work that is done by force does not have any impact. Moreover, the mothers do it with a 
loud voice. Mothers need to know that children have stages called the initiative and guilt stage. This means that children can already be given responsibility for a task, but of course it requires a process. The inability to complete it and the label that may be accepted by the children, will make the children feel guilty. In fact, it is not impossible that the guilt will develop into insecurity. To be able to increase this initiative, what mothers need to do is to give trust to the children along with an explanation of the importance of completing the assigned task. Often a loud voice accompanied by yelling will also result in the message being conveyed not well received by the children. Markham [16] also wrote that based on the results of research, children who often get yelling tend to be more aggressive, both physically and verbally. So that instead of pushing out loud, it would be better if the mothers fostered a positive understanding and became a role model for her children [4].

Regarding the role of the mothers as a motivator, it can be seen that of the five subjects, $100 \%$ stated that they gave praise and encouraged the children when the children were tired or lazy to do or complete the task. Then $60 \%$ stated that they also give rewards to children who successfully complete their assignments. Only $40 \%$ give no gifts. Every action that is successfully completed by the children certainly needs to get appreciation from the mothers to maintain and even increase his motivation. Nurmasita and Rofiah [7] explain that parents must always provide motivation in the form of love, attention, encouragement, and the presence of parents by their side in the hope that children do good and leave God's prohibitions.

Likewise, if there is no success or the attitude of not wanting to complete or do a task, of course there needs to be action to change that. Based on the results of the questionnaire, it is known that the punishments that were carried out when the children did not carry out their responsibilities, as many as $80 \%$ of respondents chose to confiscate items that the children liked and $60 \%$ chose not to allow children to play. Giving punishment, of course, must also pay attention to age and existing situations also conditions. Sabartiningsih, Muzakki, and Durtam [17], write that "gives a reward when the children performs a good action and gives punishment when the children performs an unlawful acts always consider the age and situation and conditions for the provision of rewards and punishment in accordance with the needs". In addition, punishment cannot be in the form of physical punishment, as stated by Rianawati [4] that giving punishment cannot be in the form of physical punishment, but taking what the children like can be done. Likewise Haswell, Hock, \& Wenar (1981); Kochanska \& Aksan (1995); Kopp (1982); Kuczybksi \& Kochanska (1995); Power \& Chapieski (1986) in Papalia, Olds, and Feldman [15] wrote that "avoid physical punishment. It is often ineffective and may even lead a toddler to do more damage.".
Reward, punishment, and reinforcement are actions that can be taken to shape or change behavior, in this case from irresponsible or not yet responsible behavior to having the actual responsible behavior. This is as stated by B.F. Skinner [14] “... learning as controlled by system of rewards and punishment." The giving of rewards and punishments is proven to have a positive impact in shaping children's behavior, including responsibility. This is in accordance with the results of research conducted by Raihan that "the provision of rewards and application of rewards and punishment have made the students more motivated in following the learning process" [18].

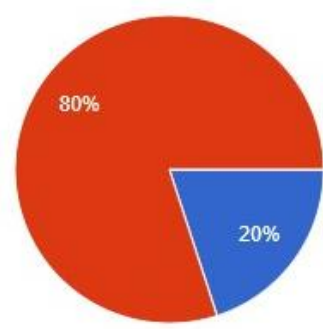

Tend to have the attitude and behavior to do something without being toid

Tend to have the attitude and behavior to do something after being told once

Tend to have the attitude and behavior to do something after being told many times

Tend to have the attitude and behavior to do something after being told and not completed properly

Figure 1 Children's Responsibility Level

It is not easy to develop responsibility for children, especially the ones aged 4-6 years. Based on Figure 1, it can be seen that $100 \%$ of respondents stated that the children's responsibility is at level 2, which happened to $80 \%$ of respondents and means that the children want to work when reminded, and $20 \%$ is at level three, which means that the children wants to work without being asked or without being reminded and accordingly with the assigned task, although the ability to provide assistance has not been seen. This means that responsibility has been attached to the children. This shows that developmentally, children aged 4-6 years have experienced good social and emotional development where according to their social development, they become more self-aware, can follow orders and some rules, can participate in various activities, and want to be the first. Emotionally, children can also control themselves, and learn the rights and wrongs [14].

Understanding aspects of children development, especially regarding responsibilities, is important for mothers, especially in the process of direct assistance for children development during the Covid-19 pandemic. 
Mothers who "do not understand" their children can lead to mistakes in parenting that have impacts on the "production" of children who are disobedient, cannot respect others, do not know manners or attitudes, etc. [4], and their success can make them grow and develop according to their age [2].

\section{CONCLUSION}

Developing responsibility must be carried out on children from the early age so that they are accustomed to being responsible and become an inherent attitude for children. It takes serious effort from parents, especially mothers, to do this specifically during the Covid-19 pandemic which requires children to learn from home. Based on the results and discussions of the research, it can be concluded that parents have understood the meaning of responsibility and responsibility attitude that children aged 4-6 years should have.

The development of responsibility is carried out in various ways including providing rewards, and punishments in the form of reducing children's enjoyment according to their age. The role played by mothers in developing responsibility for their children consists of the first, third, and fifth subjects carrying out their roles as mediators and motivators. While the second and fourth subjects carry out their roles as mediator and facilitator. There are no respondents who carry out all three roles at once, especially as both motivator and facilitator. What is important for mothers to do is consistency in implementing agreements accompanied by the ability to explain so that children carry out their responsibilities without being forced in a soothing and pleasant voice..

\section{ACKNOWLEDGMENTS}

Thank you to the Institute for Research and Community Service, University of Al Azhar Indonesia for funding the international seminar grant given to participate in the International Online Conference Early Childhood and Primary Education 2020 activities.

\section{REFERENCES}

[1] A. N. Yahya, I. Rastika, The government changes the term social distancing to physical distancing, KOMPAS.com.

2020. https://nasional.kompas.com/read/2020/03/23/1433 2461/pemerintah-ubah-istilah-social-distancingjadi-physical-distancing

[2] A. T. A. Werdiningsih, K. Astarani, The Role of Mother in Fulfilling the Basic Needs of Children in the Development of Preschool Age Children, Jurnal STIKES, 2012, 5(1), pp. 82-98.
[3] Zubaedi. Optimizing the Role of Mothers in Educating Early Childhood Character in Today's Age. Jurnal Al Fitrah, 2019, 3(1), pp. 49-63.

[4] Rianawati. The Role of Mother in Early Childhood Character Education According to Islamic View, Raheema. Jurnal Studi Gender dan Anak, 2014, 1(1), pp. 1-13. Doi: https://di.org/10.24260/raheema.v1i1.146.

[5] C. B. Pangesti, W. D. Agussafutri, Relationship between Mother's Role and Self-Concept in 3-5 Years Old Children, Jurnal Kesehatan Kusuma Husada, 2017, pp. 160-165.

[6] Psikodemia.com, Eric Erikson's Stages of Psychosocial Development, Psikodemia.Com, $2017 . \quad$ https://psikodemia.com/tahapanperkembangan-psikososial-eric-erikson/

[7] N. Nurmasita, N. H. Rofiah, The Role of Parents in Cultivating Responsibilities of Students of SD Muhammadiyah Ambarketawang 2 Gamping, Jurnal Fundadikdas (Fundamental Pendidikan Dasar), 2018. 1(1), pp. 73-83. https://doi.org/10.12928/fundadikdas.v1i1.72

[8] J. Surifah, L. Rosidah, Fahmi, The Influence of Habitual Methods on the Formation of Responsible Attitudes for Children aged 4-5 Years, Jurnal Penelitian Dan Pengembangan PAUD, 2018, 5(2), pp. 113-123.

[9] T. Lickona, Character Matters (How to Help Children Develop Good Assessment, Integration, and Other Important Policies), PT Bumi Aksara: 2015, p. 258.

[10] Kementerian Pendidikan dan Kebudaayaan Republik Indonesia, Develops responsibility for children, Family Friends, Jakarta. 2016

[11] R. I. Haryani, I. Jaya, Yulsyofriend, The shaping of a responsibility character in the Budi Mulia Padang Islamic Kindergarten, Jurnal Ilmiah Potensia, 2019, 4(2), pp. 105-114. https://doi.org/https://doi.org/10.33369/jip.4.2.105114

[12] S. Abdussalam, How to Educate Children from Birth to Kindergarten, PT Elba Fitrah Mandiri Sejahtera, 2012.

[13] A. I. Ramiyati, Halida, Increased Responsibility through the Method of Assigning Children aged 45 Years in Kindergarten, PG-PAUD FKIP Universitas Tanjungpura Pontianak, 2012, pp. 118.

[14] J.A. Brewer, Early Childhood Education. Preschool through primary grades. Sixth Edition. Pearson. Allyn and Bacon, 2007. 
[15] D.E. Papalia, Olds, S. Wendkos, and R.D. Feldman, A Child's World Infancy through adolescence. Ninth Edition. McGraw Hill, 2002.

[16] A.P. Anggraini, Negative Impact of Often Yelling at Children, Parents Must Know, Kompas.com. 07/03/2020.

[17] M. Sabartiningsih, J.A. Muzakki, D. Durtam, The Implementation of Reward and Punishment in
Establishing Discipline Character in Children, Awlady: Jurnal Pendidikan Anak. 2018, Vol. 4 No. 1, pp. 60-77.

[18] Raihan, Application of Rewards and Punishment in Improving Learning Achievement of Islamic Religious Education for High School Students in Pidie Regency, DAYAH: Journal of Islamic Education, 2019, Vol. 2, No. 1, pp. 115-130. 